\title{
The Ability to Assimilate Technology as a Source of Competitive Advantage of Financial Compa- nies in Poland
}

\author{
- Glabiszewski Waldemar, Zastempowski Maciej
}

\begin{abstract}
This article is empirical in nature and attempts to assess the impact of ability to assimilate newly acquired technologies by financial companies operating in Poland gaining market competitive advantages. The outcome of the research conducted proved the existence of this relationship and found it be strong. This means that the development of these abilities within the absorptive potential of financial companies should trigger a significant increase in the market competitive advantages held by them. The strong impact was identified both in the total of the analyzed personnel and general-organizational components of the assimilation abilities. As regards elementary components of the analyzed potential, the obtained results are definitely more diverse.
\end{abstract}

Keywords: absorptive capacity, technology transfer, competitive advantage, abilities JEL Classification: $M 10$

\section{INTRODUCTION}

Nowadays, competitiveness of companies is largely dictated by their technological advancement and dynamically changing, and thus increasingly challenging environment, causes that individual assurance of advanced technologies is an extremely difficult task, even for large and powerful entities. This difficulty stems from the challenges posed by conditions that are present primarily in the competitive and technological environment. They enforce almost every company to resort to technological solutions originating from outside the organization. This raises the need for companies to transfer new technologies from external sources to their own, de facto, totally new environment for these technologies. Thus, they must be properly assimilated, which involves the broadly understood adaptation of an important technological solution to the needs and conditions of the recipient.

An important success factor in the process of technology transfer appears to be, therefore, the company's ability to assimilate it. However, the success is not reflected by the sheer fact of the acquisition, or even of the implementation of new technologies in the business, but by such an implementation that would ensure the generation of competitive effects, and the obtainment of the desired results due to its operation. Therefore, the ability to assimilate technology does not mean only getting to know and using it, but also transforming it appropriately, which requires applying diverse and demanding resources, deciding about the strength of capabilities being cocreated. The company's staff that is responsible for technology transfer, in particular managers, must therefore be fully aware of the structure and the role of assimilation potential in building technological and market competitive advantages, which is the major issue discussed within this 
article. However, the authors particularly attempt to answer the following question - 'To what extent does the development of ability to assimilate newly acquired technologies affect the size of market competitive advantages gained by companies operating in the Polish sector of commercial financial services?'

\section{THE ESSENCE AND IMPORTANCE OF PRO-TECHNOLOGICAL ASSIMILATION ABILITIES OF COMPANIES}

The process of technology transfer is a sequence of cyclically repeated activities of a specific structure (Walter, 2003). Contrary to appearances, it is a frequent subject of controversy in the subject literature, since it is difficult to determine the beginning and end of this complex process going beyond the boundaries of the organization, as well as to indicate critically an enumerative list providing elementary tasks to be performed within the process. As a result, one can come across a number of proposals of structuring the technology transfer process - from general (Fernez-Walch \& Romon, 2005) to very specific ones (Walter \& Heinrichs, 2011). In this study, the authors relied on dominant literature perception of the technology transfer process. From the perspective of the recipient, it is composed of three basic, however, internally differentiated and structured stages, namely (Cohen \& Levinthal, 1990; Zahra \& George, 2002; Todorova \& Durisin, 2007):

- acquiring new technology,

- assimilating the acquired technology,

- using the assimilated technology.

This process, therefore, cannot be reduced - as it might seem - to the purchase or acquisition of technology, or even to its implementation, but also includes its operation that is full absorption in order to achieve the desired effects. As already suggested, these steps are only the basis for further operationalization of the transfer process, due to which it can gain a more applicational character. It looks similar in case of the second stage that defines the focus area of the present article (Lubbe \& Brent, 2009). Although it is highly integrated both with the preceding stage and with the subsequent one, the stage should anticipate within its structure clearly separated activities dedicated only to it. It happens frequently that the process of assimilation of technological knowledge is reduced only to its acquisition (Zahra, George 2002). However, the acquired technology requires also to be internalized and integrated, that is to be adapted to the new environment, which implies the need for its transformation that boils down to its development by combining selected elements of the newly acquired technology to the desired elements of the technology already possessed (Fichman \& Kemerer, 1999, Szulanski, 1996). Therefore, assimilation is not only learning of the new technology, but also its adaptation and transformation leading even to its improvement, thus giving it or increasing its degree of innovation.

If a company is to be able to successfully carry out such a complex and difficult undertaking, it must possess a set of certain abilities that need to be specialized and undoubtedly of huge capacity, and these abilities decide about its absorption potential. The abilities to assimilate the newly acquired technologies from the environment are, apart from the company's ability to acquire 
and exploit it, a segment of pro-technological absorption abilities of the company, as presented in Figure 1.

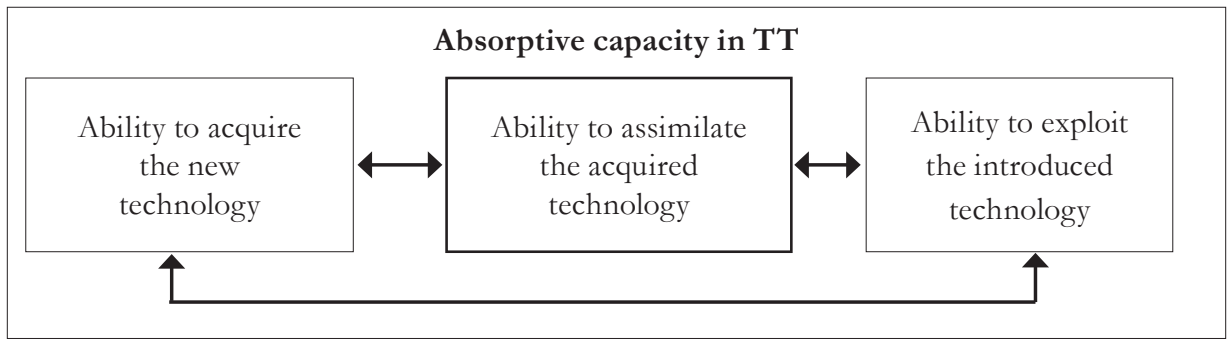

Fig. 1 - Segments of absorption potential in the TT process. Source: elaborated by the authors.

These aggregated segments of abilities, co-creating the absorption potential, are clearly dependent on each other, both in the process of their forming and use (Zahra \& George, 2002). Moreover, they are complex in nature, which means that they are built up of numerous elementary components, some of which are universal in nature, and some are specialized. The former can be applied at various stages of technology transfer, and decide about the effectiveness of different actions. These include, for instance, technical knowledge of workers, their entrepreneurial attitudes, as well as market-oriented organizational culture, or a pro-innovative incentive system. In turn, the latter are used to implement specific tasks within a functionally separated area requiring high expertise. Therefore, the abilities to assimilate newly acquired technologies should, due to their profiled use, anticipate (Glabiszewski, 2015):

- ability to learn gained technologies,

- ability to adapt gained technologies,

- ability to develop gained technologies.

The strength of the entire absorption potential and of the aggregated segments is derived from the individual elementary components which are the company's specific resources being the source of individual abilities (Trott, 2008). Therefore, they should be purchased or shaped in a planned manner, bearing in mind the fact that they may be both individual (personal) in nature (Stankiewicz \& Moczulska, 2015), the carrier of which are individual employees (Fedotova, Loseva \& Kontorovich, 2016), as well as general-organizational, which makes the organizational capital of the company (Barney, 1997). Among the specialized personnel resources which determine the ability to gain new technologies from outside and are not the universal components of the absorption potential, the following can be distinguished (Glabiszewski, 2016):

- the tendency of employees to learn,

- expertise and skills in the area of research and development,

- staff experience in the sphere of technology implementation and improvement,

- motivation for implementing innovative changes in the newly acquired technologies,

- managers' knowledge of change management. 
In turn, within the specialized general-organizational resources which are typical of the sphere of the potential responsible for the acquisition of new technologies, the following should be anticipated (Glabiszewski, 2016):

- assimilation procedures and processes, adaptation and improvement of knowledge and technology,

- good intra-organizational employee relationships and mutual trust,

- technical equipment of individual workplaces,

- a separated organizational entity responsible for continuous implementation of R\&D,

- specialized R\&D equipment (for example, instruments, equipment, software),

- the level of the R\&D budget,

- available on-premises infrastructure determining the applicability of technology.

When shaping individual components of pro-technological absorption potential, including the ability to acquire new technologies, it must be assumed that the level of their development determines ultimately the ability to obtain, using this technology, a competitive advantage and high performance in the process of competing. Therefore, they can play a very responsible role not only in the TT process, but ultimately also in the market and financial activities of the entire organization (Lane, Koka \& Pathak, 2006).

\section{METHODOLOGY AND HYPOTHESES}

The empirical part of the article was written on the basis of the research done by the author in 2014-2015 with the use of an online survey. It was sent to the heads of 155 commercial companies of the finance sector registered in Poland, namely all banks, property and life insurance companies, investment funds (TFI) and universal fund management companies (PTE). Eventually, 108 entities took part in the study by filling in the online survey questionnaire. They constituted $70 \%$ of the studied population. As a result, measurement and analysis were performed for 37 TFIs, 26 banks, 19 property insurance companies, 17 life insurance companies and 9 PTEs.

The research conducted was the primary source of data needed to achieve the main empirical objective of the article, which is the assessment of impact of the abilities of financial companies operating in Poland to assimilate newly acquired technologies on gaining market competitive advantages by these companies. In order to achieve the aforementioned main objective, the authors set three other more detailed objectives, namely:

1. to evaluate the influence of the aggregated area of abilities to assimilate newly acquired technologies on gaining competitive advantage in market conditions in comparison to other areas of the absorption potential;

2. to evaluate the influence of specific segments of abilities to assimilate newly acquired technology on gaining competitive advantage in market conditions;

3. to evaluate the influence of individual components of abilities to assimilate newly acquired technologies on gaining competitive advantage in market conditions. 
In order to carry out the specific objectives as well as the article's primary objective, the authors put forward for verification three following research hypotheses:

1. The level of development of financial companies' aggregated abilities to assimilate newly acquired technologies strongly influences acquiring market competitive advantages;

2. All of the three segments of financial companies' abilities to assimilate newly acquired technologies influence strongly gaining market competitive advantages;

3. Both the elementary resources that are individual and general-organizational, co-creating specialized abilities to assimilate newly acquired technologies influence significantly gaining market competitive advantages.

In order to verify the above hypotheses, the authors carried out statistical and descriptive analyses of the obtained findings, reaching the conclusions presented in the subsequent section.

\section{THE IMPACT OF ABILITY TO ASSIMILATE TECHNOLOGIES ON GAINING COMPETITIVE ADVANTAGES}

The company's ability to assimilate technologies acquired from outside together with the ability to acquire and exploit their potential form the absorptive potential applicable in the process of technology transfer. As a coherent system, it should provide the introduction of innovative technology to the company and such a use of this technology so that it could become a source of competitive advantages, enabling the company the implementation of market and financial goals underlying the decision on its implementation.

During the conducted research, up to $70 \%$, i.e., 76 entities in question, declared that in the previous three years they had been able to achieve a clear technological advantage over their sector direct rivals due to the absorbed innovative technology. However, possessing a resource advantage, which is a technological advantage, makes economic sense only when based on that, it is possible to create a competitive advantage. This in turn is reflected in the possessed attribute advantages of the company's offer perceived by customers. In other words, the offer must have sufficiently high value relative to competitors, so that customers were encouraged to choose it. In order to verify whether this task has been successfully completed by financial companies in Poland, their managers were asked to specify a percentage scale of the level of achievement of the market advantages constructed with the assumption of technological resource advantages. The average grade level obtained at the level of $67.7 \%$ indicates that the surveyed companies managed to build market competitive advantages, though not as large as they had expected. However, taking into account the significant competitive power of their market rivals and the resulting high intensity of competition in the financial sector, the gained advantages should be regarded as significant, though - as it turns out - not always fully satisfactory.

Therefore, it raises a persistent question of the impact of financial companies' ability to assimilate the newly acquired technology of gaining market competitive advantages. To answer it, in the first step within the analyses made, we estimated Pearson's correlation coefficients for the diagnosed level of development of these abilities and of achievement of market competitive advantages. In both areas, the measurement was made using a percentage scale ranging from 
0 to $100 \%$. In the first one, 0 on the scale means that these abilities were actually not developed, and $100 \%$ means a maximum, i.e., they were fully developed. In the second case, 0 meant that the competitive advantage was not gained at all, and 100\% - it was achieved at the target level, which is consistent with the strategic objectives of the company. The obtained coefficients are shown in Table 1.

Tab. 1 - Pearson's correlation coefficients for the level of development of individual absorption abilities and the level of achievement of the market competitive advantages

\begin{tabular}{|l|c|}
\hline \multirow{2}{*}{ Variables } & $\begin{array}{c}\text { The level of gaining competitive } \\
\text { advantage in the market }\end{array}$ \\
\cline { 2 - 2 } & $r$ \\
\hline $\begin{array}{l}\text { The level of development of the ability } \\
\text { to acquire new technologies }\end{array}$ & $0.504 \dagger$ \\
\hline $\begin{array}{l}\text { The level of development of the ability } \\
\text { to assimilate new technologies }\end{array}$ & $0.624 \dagger$ \\
\hline $\begin{array}{l}\text { The level of development of the ability } \\
\text { to use assimilated technologies }\end{array}$ & $0.443 \dagger$ \\
\hline
\end{tabular}

$* \mathrm{p} \leq 0.1 ; * * \mathrm{p} \leq 0.05 ; * * * \mathrm{p} \leq 0.01 ; \dagger \mathrm{p} \leq 0.001$

Source: own study based on survey results.

The presented Pearson's coefficients indicate the existence of a positive correlation occurring between the studied variables. This means that further development of absorption abilities should provide financial companies with a higher level of a market competitive advantage, which they intend to acquire as a result of TT, but the growth will not be necessarily substantial. However, the largest impact on the increase in the size of a competitive advantage is exerted by the level of development of the ability to assimilate a new technology, as only between these variables, a strong linear relationship was diagnosed $(r=0.62)$. In case of the level of development of ability to acquire new technologies, as well as relative to ability to use it, this dependence is rather moderate (Wasilewska, 2008). The estimated level of correlation allows, therefore, confirming hypothesis $\mathrm{H} 1$ which assumes that the degree of development of the aggregated abilities to assimilate newly acquired technologies held by financial companies strongly influences gaining market competitive advantages. It is also worth adding that more strongly than the ability to capture, as well as to exploit new technologies. This seems to be most reasonable when taking into account the structure of this area of absorption potential, as well as the functions assigned to the individual segments. At the stage of assimilation of the technology acquired from outside, it is assimilated not only through getting new know-how, but also through adapting it to the operational environment that is new for it. Moreover, changes made during the adjustment processes can be intended not only to adapt new technological solutions, but also to improve them, thus creating the ground for increases in its level of innovation, and, consequently, in the competitive advantage being achieved.

In the next step, with a view to deepening the knowledge of the examined dependence, Pearson's correlation coefficients were estimated for the diagnosed level of development of the three separate segments identified within financial companies of the ability to assimilate newly acquired 
technologies and the level of achievement of the market competitive advantages. Their values are presented in Table 2 .

Tab. 2 - Pearson's correlation coefficients for the level of development of the segments of ability to assimilate newly acquired technologies and the level of achievement of the market competitive advantages

\begin{tabular}{|l|c|}
\hline \multirow{2}{*}{ Variables } & $\begin{array}{c}\text { The level of gaining competitive } \\
\text { advantage in the market }\end{array}$ \\
\cline { 2 - 2 } & $r$ \\
\hline Ability to learn gained technologies & $0.469 \dagger$ \\
\hline Ability to adapt gained technologies & $0.635 \dagger$ \\
\hline Ability to develop gained technologies & $0.604 \dagger$ \\
\hline
\end{tabular}

${ }^{*} \mathrm{p} \leq 0.1 ; * * \mathrm{p} \leq 0.05 ; * * * \mathrm{p} \leq 0.01 ; \dagger \mathrm{p} \leq 0.001$

Source: own study based on survey results.

The obtained values of correlation coefficients confirm the existence of a linear relationship between the analyzed variables although its intensity levels vary. A strong influence was diagnosed in two of the three examined relationships, namely, with regard to ability to adapt the acquired technology and its extension. However, in case of ability to absorb, the correlation should be considered at most as moderate. Thus, there are reasons to falsify the hypothesis $\mathrm{H} 2$ which assumes that all of the three segments of financial companies' abilities to assimilate the newly acquired technologies influence strongly gaining market competitive advantages.

This hypothesis stemmed from an assumption made by the authors, according to which the strength of assimilation potential depends on the level of the development of all three segments co-creating it, since in practice, it is difficult to clearly distinguish them by setting clear boundaries between them. They constitute a tightly integrated composition, deciding about the efficiency of activities of the company undertaken within the process of assimilation of new technologies. It turns out, however, that in accordance with assumptions of the theory of innovation and competitiveness, the level of competitive advantage is influenced primarily by those company abilities which predispose it to undertaking innovative activities. In case of assimilation potential, these are, therefore, the abilities to improve technology, resulting either from the need to adapt it to conditions in a particular company, or from a desire to enrich it with new solutions that have not been used previously by competitors.

The awareness of strong dependence between the analyzed abilities and the effects obtained as a result of their use, should prompt managers to develop the ability to improve the acquired technology in the company. As turns out, this is the most justified investment from the perspective of the need to shape the company's high competitiveness. In practice, development of potential, however, requires the designation of precise directions of changes relating to its specific components. As a result, what becomes expedient is a detailed assessment of the impact of individual specialized components of the ability to assimilate newly acquired technologies on the size of the market competitive advantage obtained due to these technologies. Therefore, in a further part of the analysis, we determine the level of Pearson's correlation coefficients for the variables which are shown in Table 3. 
Tab. 3 - Pearson's correlation coefficients for the level of development of particular components of ability to assimilate newly acquired technologies and the level of achievement of the market competitive advantages

\begin{tabular}{|c|c|c|}
\hline \multirow[t]{2}{*}{ No. } & \multirow[t]{2}{*}{ Variables } & $\begin{array}{c}\text { The level of gaining } \\
\text { competitive advantage } \\
\text { in the market }\end{array}$ \\
\hline & & $r$ \\
\hline \multicolumn{2}{|c|}{ Employees' individual assets } & $0.688 \dagger$ \\
\hline 1 & $\begin{array}{l}\text { Motivation for implementing innovative changes in the } \\
\text { newly acquired technologies }\end{array}$ & $0.688+$ \\
\hline 2 & $\begin{array}{l}\text { Expertise and skills in the area of research and develop- } \\
\text { ment }\end{array}$ & $0.645 \dagger$ \\
\hline 3 & Managers' knowledge of change management & $0.579 \dagger$ \\
\hline 4 & Tendency of employees to learn & $0.569 \dagger$ \\
\hline 5 & $\begin{array}{l}\text { Staff experience in the sphere of the technology imple- } \\
\text { mentation and improvement }\end{array}$ & $0.568 \dagger$ \\
\hline \multicolumn{2}{|c|}{ Assets related to general organization } & $0.667 \dagger$ \\
\hline 1 & The size of $\mathrm{R} \& \mathrm{D}$ budget & $0.595 \dagger$ \\
\hline 2 & $\begin{array}{l}\text { Assimilation procedures and processes. adaptation and } \\
\text { improvement of knowledge and technology }\end{array}$ & $0.562 \dagger$ \\
\hline 3 & $\begin{array}{l}\text { A separated organizational entity responsible for con- } \\
\text { tinuous implementation of R\&D }\end{array}$ & $0.546 \dagger$ \\
\hline 4 & Technical equipment of individual workplaces & $0.495 \dagger$ \\
\hline 5 & $\begin{array}{l}\text { Good intra-organizational employee relationships and } \\
\text { mutual trust }\end{array}$ & $0.430 \dagger$ \\
\hline 6 & $\begin{array}{l}\text { Specialized R\&D equipment (e.g., instruments. equip- } \\
\text { ment. software) }\end{array}$ & $0.424 \dagger$ \\
\hline 7 & $\begin{array}{l}\text { Available on-premises infrastructure determining the } \\
\text { applicability of technology }\end{array}$ & $0.348 \dagger$ \\
\hline
\end{tabular}

$* \mathrm{p} \leq 0,1 ; * * \mathrm{p} \leq 0,05 ; * * * \mathrm{p} \leq 0,01 ;+\mathrm{p} \leq 0,001$

Source: own study based on survey results.

The estimated values of Pearson's correlation coefficients for the averaged level of development of personal and general-organizational resources co-creating specialized abilities to assimilate newly acquired technologies indicate their significant impact on gaining market competitive advantages $(r>0.6)$, which confirms the correctness of the adopted hypothesis H3. However, it is not confirmed by all of Pearson's correlation coefficients determined for the elementary components of this specialized absorption potential. The strong impact was detected only in the case of two individual resources, i.e., motivation employees have to implement innovative changes in the newly acquired technologies and the expertise and skills possessed by employees within the research and development work being conducted. These are primarily those elements of the assimilation potential that must be improved, since - as it turns out - they influence most the level 
of their offer's advantage perceived by customers, and thus make it possible for the company to achieve the biggest market effects.

A substantial impact on the level of market competitive advantages $(0.6>r$, but $>0.55)$ is also exerted by the other three personnel resources of the specialized assimilation potential. This means that within the priority directions of development of the absorption ability, the following components should be included: managers' knowledge in the area of change management, tendency of employees to learn, and experience of workers gained during the implementation and improvement of previously acquired technologies.

A significant role in building market competitive advantages also play three out of the seven specialized general-organizational resources separated within the assimilation potential. The strongest influence among them exerts the size of budget allocated by the company to carry out work in the area of $\mathrm{R} \& \mathrm{D}(r=0.6)$. Therefore, investment growth in pro-technological research and development activity brings tangible market benefits to financial companies, which justifies this kind of activity and costs borne by them.

Thus, we can conclude that the intellectual or infrastructure potential of the surveyed companies does not constitute significant limitations in this regard. It also seems reasonable to engage in improvement of assimilation processes and procedures, adaptation and extending the knowledge and technology in the company, and isolating within the organizational structure a unit responsible for the continued implementation of R\&D, aimed also at improving technological solutions being implemented.

At most moderate is the relationship between the level of competitive advantages achieved by the surveyed companies and development of the following other three general-organizational components of the assimilation potential: technical equipment of individual workplaces, good intra-organizational relationships held between employees and their mutual trust, and specialist equipment in the area of $\mathrm{R} \& \mathrm{D}$, including, for instance, instruments, devices, or specialized software. So the principle is confirmed that service companies, which undoubtedly include financial companies, do not require a very high level of technical equipment, even in the sphere of research and development aimed at improving the technology being implemented. However, some reflections are arisen by the fact that the development of relationships between employees and the ensuing mutual trust does not bring significant growth in the achieved competitive advantages. Justification for this state of affairs should be sought in the fact that good intraorganizational relationships support sharing and disseminating knowledge in the organization, including technological knowledge, which facilitates the absorption of new technologies. However, as already pointed out in this article, the ability to absorb new technologies does not affect significantly increases in its innovation and, consequently, in building a competitive advantage, which has been proved here.

A weak linear relationship between the analyzed variables was noted only in the on-premises infrastructure that was available in the surveyed companies, which determines the possibilities - especially spatial, but also technical ones - of applying new technologies as well as their improvements. It turns out that these aspects of financial companies are not the barriers to building market competitive advantages through innovative technologies obtained in a form of transfer. 


\section{CONCLUSION}

Abilities to assimilate newly acquired technologies are very important, although are not always a fully conscious element of absorption potential, which is responsible for ensuring that a technology acquired by the company through transfer could be effectively exploited and generate the expected market effects. Eventually, these abilities should condition the implementation of the company's strategic objectives, in particular those for achievement of which the company has decided to absorb a new technology.

The results of the empirical studies presented in this article confirm the aforementioned assumption. As turns out, development of the ability to assimilate newly acquired technologies remains in strong connection with the size of the achieved market competitive advantages by financial companies operating in Poland. A strong impact on competitive advantages was diagnosed also with regard to specialized segments of these abilities which are the ability to adapt and expand the acquired technology, that means those that are responsible for the possible increases in technology innovation, and, consequently, in competitiveness of the company. A special role in this regard is played by two resources that are personal in nature, namely, motivation employees have to implement innovative changes in the newly acquired technologies, and their expertise and skills in the area of research and development. Primarily these components of assimilation potential should be improved, since they give the company the most desired market effects, constituting an advantage over its rivals in the sector.

The diagnosed impact of the assimilation potential on the level of the achieved competitive advantages by financial companies, which is very important from the point of view of achieving their market successes, justifies the need to undertake the research problem analyzed in this study and at the same time leads to its further exploration, in particular with a view to formulating valuable recommendations for economic practice.

\section{References}

1. Barney, J. B. (1997). Gaining and sustaining competitive advantage (134-175). Reading, MA: Addison-Wesley.

2. Cohen, W. M., \& Levinthal, D. A. (1990). Absorptive capacity: A new perspective on learning and innovation. Administrative science quarterly, 128-152.

3. Fichman R.G., Kemerer C.F. (1999). The illusory diffusion of innovation. An examination of assimilation gaps. Information systems research, 10(3), 255-275.

4. Glabiszewski, W. (2016). Potencjał absorpcyjny przedsiębiorstw finansowych w Polsce w procesie transferu innowacyjnych technologii, Wydawnictwo Naukowe Uniwersytetu Mikołaja Kopernika, Toruń.

5. Glabiszewski, W. (2015). The model of the absorption of innovative technologies in the financial services sector. International Journal of Business Excellence, 8(4), 471-491.

6. Lane, P. J., Koka, B. R., \& Pathak, S. (2006). The reification of absorptive capacity: A critical review and rejuvenation of the construct. Academy of management review, 31(4), 833863. 
7. Loseva, O., \& Kontorovich, O. (2015). Monetary valuation of intellectual human capital in innovative activity (No. 134/2015).

8. Lubbe, F. H., \& Brent, A. C. (2007, September). The transfer and commercialisation of technology from south africa to foreign markets in the financial services industry. In AFRICON 2007 (1-7). IEEE.

9. Stankiewicz, J., \& Moczulska, M. (2015). The involvement of employees in knowledge management in the light of the research results. Oeconomia Copernicana, 6(2), 37.

10. Szulanski, G. (1996). Exploring internal stickiness: Impediments to the transfer of best practice within the firm. Strategic management journal, 17(S2), 27-43.

11. Todorova, G., \& Durisin, B. (2007). Absorptive capacity: Valuing a reconceptualization. Academy of management review, 32(3), 774-786.

12. Trott, P. (2008). Innovation management and new product development. Pearson education.

13. Walch, S. F., \& Romon, F. (2013). Management de l'innovation. Vuibert.

14. Walter A., \& Heinrichs S. (2011), Technologietransfer. In Albers, S., \& O. Gassmann (eds.), Handbuch Technologie- und Innovationsmanagement, Gabler Verlag, Wiesbaden.

15. Walter, A. (2013). Technologietransfer zwischen Wissenschaft und Wirtschaft: Voraussetzungen für den Erfolg (Vol. 106). Springer-Verlag.

16. Wasilewska E. (2008). Statystyka opisowa nie tylko dla socjologów. Teoria, przykłady, zadania. Wydawnictwo SGGW, Warszawa.

17. Zahra, S. A., \& George, G. (2002). Absorptive capacity: A review, reconceptualization, and extension. Academy of management review, 27(2), 185-203.

\section{Contact information}

dr hab. Waldemar Glabiszewski

Department of Enterprise Management

Faculty of Economics and Management Sciences

Nicolaus Copernicus University

ul. Gagarina 13a, 87-100 Torun, Poland

E-mail:waldemar.glabiszewski@umk.pl

professor Maciej Zastęonski

Department of Enterprise Management

Faculty of Economics and Management Sciences

Nicolaus Copernicus University

ul. Gagarina 13a, 87-100 Torun, Poland

E-mail:mz@uni.torun.pl 